\title{
Electroencephalographic Findings in Patients with COVID-19: A Single-center Experience
}

\author{
COVID-19 Tanılı Hastalarda Elektroensefalografik Bulgular: Tek Merkez Deneyimi
}

\begin{abstract}
Objective: Neurological manifestations associated with coronavirus disease-2019 (COVID-19) are broad and heterogeneous. Although the predominant clinical presentation is respiratory dysfunction, concerns have been raised about the neurological hallmarks. Many reports suggest some findings on electroencephalography (EEG) can be relevant to COVID-19.

Materials and Methods: Patients with COVID-19 admitted to hospital and referred for EEG from March 1, 2020 to February 15, 2021, were retrospectively enrolled. When research databases were queried with the terms "COVID-19 (ICD code:10: U07.3) and "EEG", total number of patients obtained was 32. Number of patients excluded due to unconfirmed diagnose with COVID-19 was 12. Twenty adult patients with certain diagnose of COVID-19 who underwent 21-electrode routine EEG during the outbreak with neurological deterioration were identified.

Results: Background abnormalities was evident in one of fourth patients $(\mathrm{n}=5,25 \%)$. Mild diffuse slowing $(\mathrm{n}=3,15 \%)$ and focal slowing $(\mathrm{n}=3,15 \%)$ with left frontotemporal tendency $(n=2,10 \%)$ were observed. Epileptiform abnormalities and seizures were detected showing focal $(n=4,20 \%)$ or generalized onset $(n=1$, $5 \%$.

Conclusion: Here we performed a retrospective single-centre study to evaluate the electroencephalographic findings in patients diagnosed with COVID-19 since it remains unknown. it needs to be more clarified with increasing number of recordings
\end{abstract}

Keywords: COVID-19, electroencephalography, epilepsy

\section{$\ddot{O} \mathbf{z}$}

Amaç: Koronavirüs hastalı̆̆ı-2019 (COVID-19) ile ilişkili nörolojik bulgular yaygın ve heterojendir. Öncü klinik bulgu solunum disfonksiyonu olmasına rağmen, nörolojik tutuluma ait soru işaretleri de ortaya çıkmaktadır. Elektroensefalografide (EEG) bazı bulguların COVID-19'a spesifik olabileceğini iddia eden birçok bildiri mevcuttur.

Gereç ve Yöntem: Bu çalışmada 1 Mart 2020 ile 15 Şubat 2021 tarihleri arasında hastaneye başvurup EEG için konsülte edilen COVID-19 hastaları geriye dönük incelendi. Veri tabanları "COVID-19 (ICD kodu: 10: U07.3) ve "EEG” terimleri ile sorgulandığında elde edilen toplam hasta sayısı 32 'idi. COVID-19 kesin tanısının doğrulanamaması nedeni ile dışlanan hasta sayısı 12 idi. Salgın sırasında nörolojik bulgusu olup 21-elektrot-rutin EEG uygulanan kesin COVID-19 tanılı 20 yetişkin hasta çalışmaya dahil edildi.

Bulgular: Zemin aktivitesi anormallikleri dört hastadan birinde belirgindi ( $\mathrm{n}=5, \% 25)$. Sol frontotemporal bölge eğilimi gösteren ( $\mathrm{n}=2$, \% 10) fokal yavaşlama $(\mathrm{n}=3, \% 15)$ ve hafif düzeyde yaygın yavaşlama $(\mathrm{n}=3, \% 15)$ dikkati çekti. Fokal $(\mathrm{n}=4, \% 20)$ veya jeneralize $(\mathrm{n}=1, \% 5)$ başlangıç gösteren epileptiform anomaliler tespit edildi.

Sonuç: Burada tek merkezde geriye dönük olarak hala belirsizliğini koruyan COVID-19 hastalarındaki elektroensefalografik bulguları değerlendirdik. Artan çalışmalar ile konunun daha netleştirilmesi gerekmektedir.

Anahtar Kelimeler: COVID-19, elektroensefalografi, epilepsi

\section{Introduction}

Coronavirus disease-2019 (COVID-19) is a severe public health threat that primarily targets the human respiratory system.
However, it is also associated with neurological manifestations, including seizures, altered mental state, and headache $(1,2)$. People with COVID-19 may continue to suffer from persistent

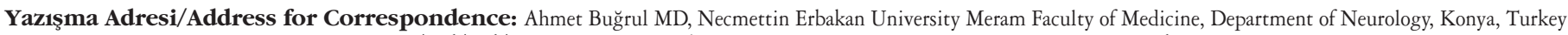
Tel.: +90 5426426432 E-posta: ahmet.bugrul@ gmail.com ORCID: orcid.org/0000-0002-6208-2553

Geliş Tarihi/Received: 10.05 .2021 Kabul Tarihi/Accepted: 03.12 .2021

${ }^{\circ}$ Telif Hakkı 2021 Türk Nöroloji Derneği

Türk Nöroloji Dergisi, Galenos Yayınevi tarafından basılmıştır. 
symptoms, including anosmia, taste loss, fatigue, anxiety, cognitive impairment, or "brain fog". Several pieces of evidence showed that neurotropic and neuroinvasive capabilities of coronaviruses may prompt seizures, convulsions, mental status changes, encephalitis, or encephalomyelitis (3). Several studies have tried to describe the typical manifestations of COVID-19 and its neurological consequences, but it remains unknown. Patients with COVID-19 may propose an increased risk with neurological deteriorations with cognitive changes or seizure-like events. However, the extent to which COVID-19 is associated with seizures is unknown. Some recent reports described the association between COVID-19 and neurological symptoms in electroencephalography (EEG) abnormality as a common feature, including background activity slowing, periodic and rhythmic activity, and epileptiform discharges (4).

New-onset seizures in a patient with COVID-19 are another important unexplored feature of this pandemic. Overall changes and outcomes of these patients and specific hallmarks of COVID-19 are still unexplored, most probably, due to the restricted number of diagnostic utilities. After more than a year of confirmation with the worldwide pandemic, we have conducted a study to evaluate the potency of EEG in patients with COVID-19-related symptoms.

\section{Material and Methods}

The Local Institutional Ethics Committee at Necmettin Erbakan University approved this study of human subjects that review the EEG and other clinical data (no: 2021/3135). For this observational and descriptive study, patients with COVID-19 who are admitted to Necmettin Erbakan University Meram Faculty of Medicine Hospital neurology department from March 1, 2020, to February 15, 2021, were retrospectively enrolled. Databases that were queried with the terms "COVID-19" (ICD code:10:U07.3) and "EEG" revealed a total number of 32 patients. A total of 12 patients were excluded due to unconfirmed COVID-19 diagnoses. Thus, 20 adult patients with certain COVID-19 diagnoses who underwent 21-electrode routine EEG (rEEG) for neurological deterioration were identified. Exclusion criteria were younger than 18 years old and were infused with anesthetics or sedating agents during or before the rEEG to avoid their confounding effects on EEG. EEGs were accomplished with the Nihon-Kohden EEG acquisition system with 32 channels. This is a standardized digital EEG recording with time-locked video. EEGs were recorded over 20 min with scalp electrodes placed according to the International 10-20-system, and portions of this record are reviewed using bandpass filters of $10-35 \mathrm{~Hz}$ with a sensitivity of $10 \mathrm{mV} / \mathrm{mm}$. Hyperventilation and intermittent photic stimulation were performed as an activating procedure and their effects were noted. EEGs are independently evaluated by two different neurologists and a clinical neurophysiologist to bring homogeneity using the American Clinical Neurophysiology Society's guideline for documentation (5). EEGs were categorized into normal or abnormal, regarding the background rhythm, periodic or rhythmic discharges, and epileptiform abnormalities. The characteristic of periodic discharges and epileptiform abnormalities as spikes and waves and periodic or rhythmic discharges were identified.

\section{Statistical Analysis}

Descriptive statistics (mean, frequency, and standard deviation) and Student's t-test on parametric data showing normal distribution were evaluated using the Statistical Package for the Social Sciences for statistical analysis.

Electronic medical records, laboratory, and radiologic testing for all patients were retrospectively reviewed. Data on age, sex, co-existing diseases, and conditions like altered mental status, headache, stroke, smell or taste changes, and neuroimaging findings (brain tomography or magnetic resonance) were collected. Any missing or uncertain records were clarified through direct communication with these patients, their health caregivers, or their families.

\section{Results}

A total of 20 adult patients with COVID-19 who underwent rEEG after neurological deterioration were identified, who were aged 22-72 years (mean: $46.8 \pm 3.3$ ), including 7 males $(35 \%)$ and 13 females $(65 \%)$. Positive severe acute respiratory syndrome coronavirus 2 nucleic acid polymerase chain reaction test on preadmission was determined in $75 \%$ (15 out of 20) of cases and the rest were diagnosed according to the chest-computed tomography $(20 \%)$ and positive anti-body test result (5\%). Of these 20 patients, one had prior epilepsy and is taking antiseizure medication (ASM). EEGs were abnormal in half of the patients, which were classified into three subgroups as follows: 1) Background abnormalities in the quarter of patients $(n=5,25 \%)$. They were further categorized into mild diffuse slowing $(n=3,15 \%)$ or focal slowing $(n=3,15 \%)$ with left frontotemporal tendency $(\mathrm{n}=2,10 \%)$. 2) Epileptiform changes and seizures were categorized into focal $(n=4,20 \%)$ or generalized. Control EEGs were concordant with the previous one in all patients (4/4). 3) Periodic or rhythmic patterns of intermittent rhythmic discharges are obtained in patients who present with new-onset seizure $(\mathrm{n}=1,5 \%)$ (Figure 1$)$.

Patient demographics, COVID-19-specific diagnostic studies, history, chief complaints, and comorbidities of patients are summarized in Table 1 . Brain MRI was performed in 17 out of 20 patients, of which 1 had consistent findings with an ischemic stroke with bilateral watershed infarcts (Figure 2), 1 had a lobar meningioma, and 8 (47\%) was normal. The investigation for the reasons for referrals revealed that the most common was cognitive changes $(n=5,25 \%)$ followed by seizure-like events $(n=5,25 \%)$. Memory disturbance $(\mathrm{n}=4,20 \%)$, confusion $(\mathrm{n}=1,5 \%)$, and attention deficit $(\mathrm{n}=1,5 \%)$ were counted as a single category and described as cognitive changes. New-onset seizure, myoclonic jerks, and recently developed opsoclonus-myoclonus without any suspicious underlying etiology other than COVID-19 were the most interesting subjects in this study $(n=3,15 \%)$ and will be discussed later on. Prolonged headache $(n=2,15 \%)$, temporary numbness or burning sensations on hands and feet $(n=3,15 \%)$, myalgia $(\mathrm{n}=1,5 \%)$, and unpleasant smell sensation or loss of taste/ smell $(n=2,10 \%)$ were the resting reasons for rEEG investigations.

\section{Discussion}

This study aimed to evaluate and assess the utility of EEG in emerging COVID-19-associated symptoms and define the presenting epileptiform abnormalities. To our knowledge, this is the first systematic study in Turkey that highlights the electroencephalographic findings with COVID-19. 


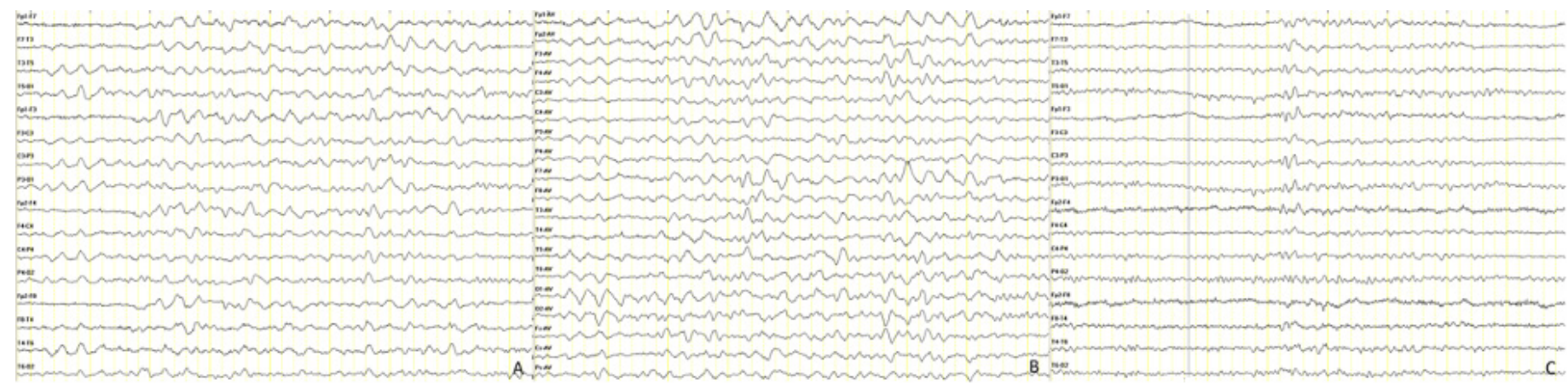

Figure 1. Intermittent rhythmic discharges in a 22-year-old female patient without a history of seizure who presents with new-onset seizure (focal-onset seizure with impaired awareness and secondary bilateral tonic-clonic activity) (A) double banana and (B) average montage, focal epileptiform discharge with following electroencephalography $(\mathrm{C})$ double banana montage

Table 1. Summary of demographic features, history, diagnostic method, and complaints with electroencephalography indication and features

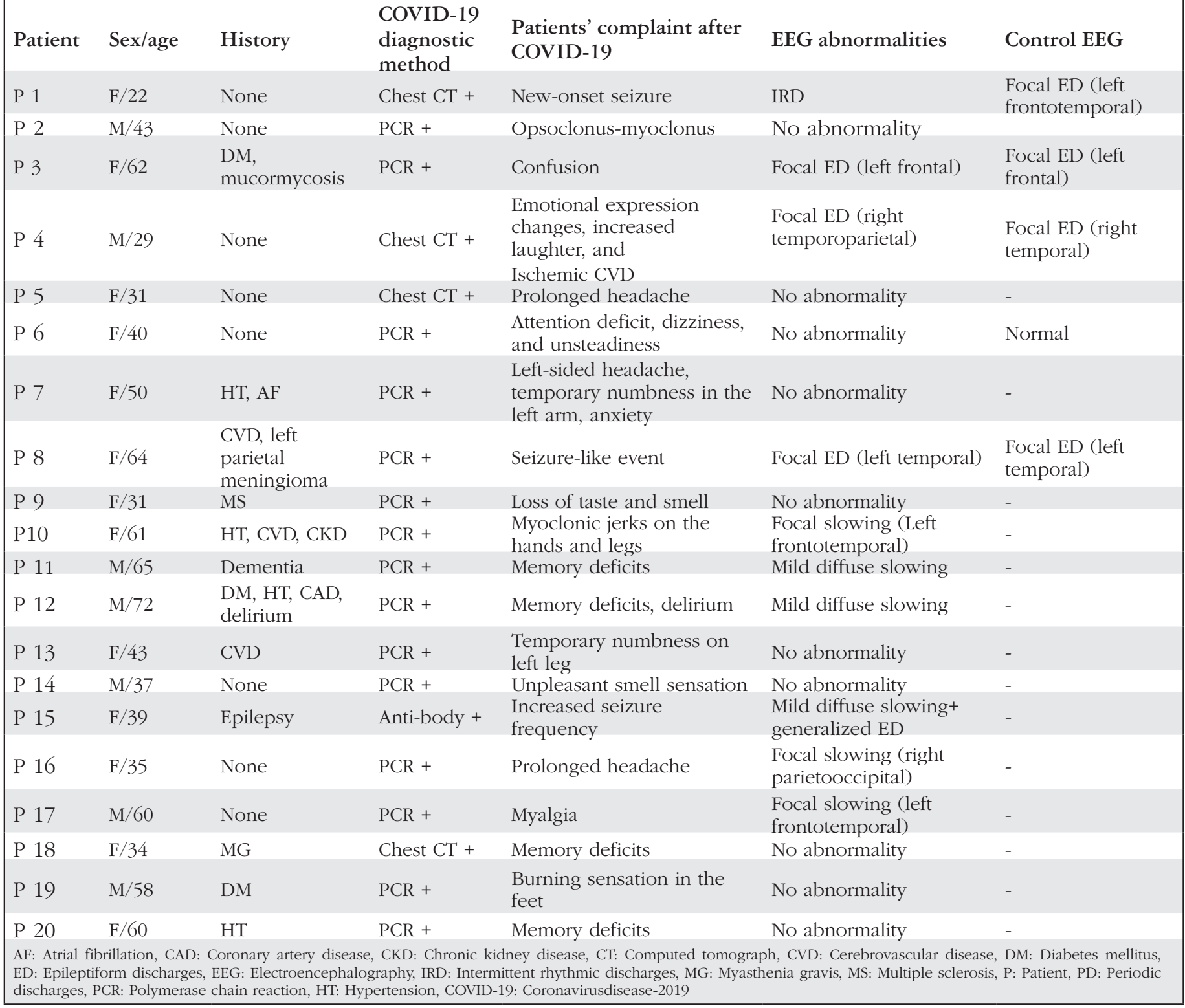




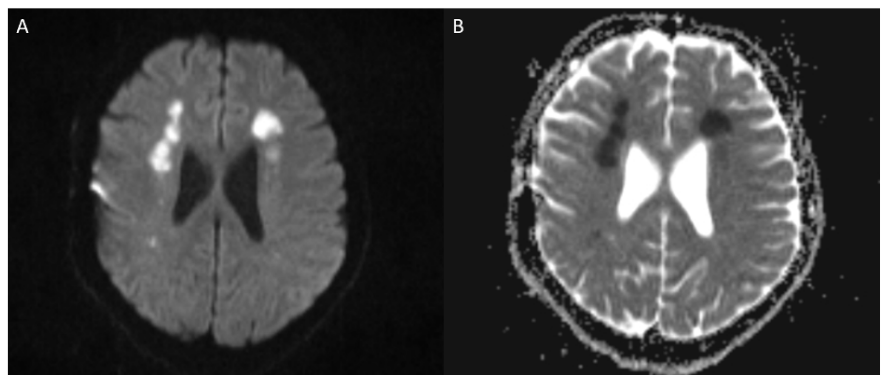

Figure 2. Diffusion (A) and apparent diffusion coefficient (B) images show bilateral internal watershed infarction that presents with acute symptomatic seizure

Seizure-like events and cognitive changes were almost the main reason to investigate an rEEG $(50 \%)$ according to the study, and abnormal EEG was reported in half of the subjects. Altered mental status (including attention deficit, memory disturbances, confusion, and delirium) even in the absence of sedating agents was reported in one-fourth of the subjects $(5 / 20,25 \%)$ after excluding the case with preexisting dementia. Antony and colleagues showed that altered mental status $(61.7 \%)$ and seizure-like events $(31.2 \%)$ were the most common reasons for EEG investigation in a systematic review (4). The incidence of altered mental status was disparate from our study, which is probably related to their older age population (The median age of their participants was 61.3 years).

Follow-up EEGs were discordant with the first one showing high reliability (4/4). The main abnormality on EEG includes background slowing with the diffuse or focal distribution. The sporadic epileptiform abnormalities were not rare $(25 \%)$, predominantly showing focal tendency that correlated with the clinical presentation. Patients with prior epilepsy have abnormal EEG $(55 \%)$ or epileptiform discharges $(30 \%)$. Follow-up EEGs were available in $20 \%$ of patients with the same features. Focal epileptiform discharges with frontotemporal dominancy (left > right) were the main features of these analyses.

Acute symptomatic seizures with ongoing seizure activity without prior epilepsy in COVID-19 infection are increasingly reported (6,7). Furthermore, recent systematic reviews suggest that patients with preexisting neurological disorders, like epilepsy, may develop neurological problem exacerbations in the setting of COVID-19 (8).

Subjects with new-onset seizures in this study presented with intermittent rhythmic discharges on admission with a frequency of $>1 \mathrm{~Hz}$, which is known to correlate with increased seizure risk $(9,10)$. Subsequent EEG revealed focal epileptiform discharges with frontotemporal lateralization. (Figure 1) Subject was seizurefree with medication.

Another subject among these patients with COVID-19 who were diagnosed with acute ischemic stroke was presented concomitant acute symptomatic seizure. Seizure control is maintained with levetiracetam at $500 \mathrm{mg}$ twice a day with gradual ASM cessation. Several days after, the patient was re-admitted to the neurology outpatient clinic with increased laughter without emotional intensity, mood changes, and attention deficit. The first and subsequent rEEG revealed right temporal epileptiform discharges in both. The patient was seizure-free in control. These attacks were not accompanied by other symptoms, like staring, automatism, or motor findings. Long-term video-EEG monitoring was eventually considered. Growing evidence of epileptiform abnormalities in the absence of prior epilepsy history was supported by our study that indicated possible cortical irritability, which predisposes to seizures.

Recent onset opsoclonus-myoclonus was one of the interesting presentations in this population. Limited numbers of opsoclonusmyoclonus cases in the setting of COVID-19 are documented (11). In this case, rEEG was normal as it was supposed to be in opsoclonus-myoclonus. Myoclonus may originate from the cortical, cortical-subcortical, subcortical-supraspinal, spinal pathways, or within the peripheral nervous system. Only cortical and cortical-subcortical areas originating myoclonus may show EEG abnormalities. Opsoclonus-myoclonus arising from subcorticalsupraspinal pathways was a unique presentation and explained the normal EEG (12).

Another patient with prior epilepsy was already on ASMs (Valproic acid at $500 \mathrm{mg}$ and Zonisamide at $400 \mathrm{mg}$ add-on therapy) at the time of admission and presented with increased seizure frequency. This patient was discharged on the gradually increased valproic acid and decreased zonisamide. The patient remained seizure-free during the hospitalization and follow-up. Frontal EEG findings resulting from direct brain involvement in a patient with confirmed COVID-19 have been speculated, whereas more systemic involvement may lead to more diffuse changes (13). Older people are speculated to have a higher risk of developing severe manifestations with COVID-19 (13). The age of our study population ranges from 22 to 72 years, 10 of whom showed EEG abnormality $(n=10,50 \%)$. They seemed slightly older than the rest; however, the difference was not statistically proven $(\mathrm{p}=0.224)$.

Our study revealed that the proportion of EEG abnormality was higher in patients with cognitive changes and seizure-like events regardless of prior epilepsy. Additionally, symptoms, such as headache or burning sensations, are less likely associated with abnormal EEG.

\section{Conclusion}

COVID-19 may contribute to electrographic seizures and seizure detection based on continuous-EEG studies. Concerns for contamination and exposure of staff have limited the diagnostic tests among these patients, thus larger studies on EEG are relatively sparse. A need for a case-control group study among patients who are negative for COVID-19 who present with similar clinical features is the main restriction of this study.

\section{Acknowledgment}

Special thanks to the laboratory technicians, Mrs. Nihal Küçükeşmeyaka and Mrs. Emine Ar1.

\section{Ethics}

Ethics Committee Approval: The Local Institutional Ethics Committee at Necmettin Erbakan University approved this study of human subjects that review the EEG and other clinical data (no: 2021/3135).

Informed Consent: Retrospective study.

Peer-review: Externally peer-reviewed.

\section{Authorship Contributions}

Concept: N.T., A.B., B.O.G., Design: N.T., A.B., B.O.G., Data Collection or Processing: N.T., A.B., B.O.G., Analysis or 
Interpretation: N.T., A.B., B.O.G., Literature Search: N.T., A.B., Writing: N.T., A.B., B.O.G.

Conflict of Interest: No conflict of interest was declared by the authors.

Financial Disclosure: The authors declared that this study received no financial support.

\section{References}

1. Asadi-Pooya AA, Simani L. Central nervous system manifestations of COVID-19: a systematic review. J Neurol Sci 2020;413:116832.

2. Asadi-Pooya AA. Seizures associated with coronavirus infections. Seizure 2020;79:49-52.

3. Bohmwald K, Gálvez NMS, Ríos M, Kalergis AM. Neurologic alterations due to respiratory virus infections. Front Cell Neurosci 2018;12:386.

4. Antony AR, Haneef Z. Systematic review of EEG findings in 617 patients diagnosed with COVID-19. Seizure 2020;83:234-241.

5. Tatum WO, DiCiaccio B, Kipta JA, Yelvington KH, Stein MA. The Texting Rhythm: A Novel EEG Waveform Using Smartphones. J Clin Neurophysiol 2016;33:359-366.
6. Hepburn C, O'Callaghan B, Stern N, Stiglitz J, Zenghelis D. Will COVID-19 fiscal recovery packages accelerate or retard progress on climate change? Oxford Rev Econ Policy 2020;36:S359-S381.

7. Zhou D, Li X. Epilepsy EEG signal classification algorithm based on improved RBF. Front Neurosci 2020;14:606.

8. Kubota T, Gajera PK, Kuroda N. Meta-analysis of EEG findings in patients with COVID-19. Epilepsy Behav 2021;115:107682.

9. Hirsch LJ, Fong MWK, Leitinger M, et al. American Clinical Neurophysiology Society's Standardized Critical Care EEG Terminology: 2021 Version. J Clin Neurophysiol 2021;38:1-29.

10. Rodriguez Ruiz A, Vlachy J, Lee JW, et al. Association of periodic and rhythmic electroencephalographic patterns with seizures in critically Ill patients. JAMA Neurol 2017;74:181-188

11. Emamikhah M, Babadi M, Mehrabani M, et al. Opsoclonus-myoclonus syndrome, a post-infectious neurologic complication of COVID-19: case series and review of literature. J Neurovirol 2021;27:26-34.

12. Caviness JN, Brown P. Myoclonus: current concepts and recent advances. Lancet Neurol 2004;3:598-607.

13. Pilato MS, Urban A, Alkawadri R, et al. EEG Findings in Coronavirus Disease. J Clin Neurophysiol 2020 Jul 1. 